\title{
Methods to detect and measure scour around bridge foundations
}

\author{
M. Al-Jubouri ${ }^{1 *}$, R. P. Ray ${ }^{1}$ \\ ${ }^{1}$ Széchenyi István University, Structural and Geotechnical Engineering Department \\ Egyetem tér 1, 9026 Györ, Hungary \\ *e-mail: muhanad.kh.99.oo@gmail.com
}

Submitted: 19/05/2021; Accepted: 11/09/2021; Published online: 18/10/2021

Abstract: Bridges are indispensable structures vital to the operation of road and rail transportation networks. Crossing rivers and artificial waterways, however, presents a risk to their foundations due to scour actions. Scour is the number one cause for bridge failures and may occur beneath any bridge, large or small, with supports located within the waterway. This paper provides a summary of present scour detection and measurement equipment and associated assessment methodologies. In this regard, particular emphasis is placed on structural health monitoring better to evaluate the presence and influence of potential scour. A Sensitivity Analysis on a newly introduced monitoring system is also assumed. Furthermore, much research has been undertaken to create a technology that can instantly identify and detect bridge scour, improving survey reliability through prior inspection and prompt intervention. This research will explore and evaluate bridge scour detection methods employed and suggest a possible path for developing the detection system to identify scour depth effectively and efficiently. Finally, our key aim is to minimize human effort in identifying and bridge scour by using a quick, easy-to-use, cost-effective process, resulting in fewer injuries and economic savings.

Keywords: water action; Bridge scour; detection methods

\section{Introduction and motivation}

Bridges are critical engineering components within transportation networks (road, rail, pipeline, and waterway) that provide a means of crossing waterways, valleys (viaducts), and other networks (road/rail overpass). As a result, they may be exposed 
to a variety of hazards, both natural and man-made. They are at the confluence of natural barriers and human networks by the very nature of their location and function. Any damage or loss of function could result in lives lost, as well as an economic and social disaster. Engineers who study bridge damage and collapse cite scour as the number one cause for loss of operational capacity. Bridge failures due to scour have been reported by ([1], [2], and [3]), with 6000 bridge failures in the USA and 140 UK rail bridge failures during 1846-2013. A database of over 600,000 US bridges was studied and compared to 1,700 collapses due to hydraulic action by [4]. They found a wide divergence of causes and evaluated many rating systems to predict performance. Scour is also identified as the bridge management risk most likely to be impacted by climate change; approximately 1 in 20 in the UK are expected to be at high risk by 2080 [5]. Given the potential impact, mitigation measures are equally daunting with costs averaging 25 to 76 million euros annually for 2040-2100 [6].

Within risk and resilience, scour is one of many natural hazards that bridges are designed to resist. Others would include wind (hurricane, tornado), flooding (high water level, high velocity, and debris), earthquake (shaking, liquefaction), and temperature extremes (thermal stresses, expansion, and contraction). Man-made hazards would include extreme traffic and vehicle loads, collisions, and accidents from vehicles as well as ships and barges. Depending on what is permitted on the bridge, there is also the possibility of fire and explosions. The recent focus on force protection for critical infrastructure highlights the potential of terrorist attacks [7].

Further assessment of risk involves quantifying the severity and recurrence of these hazards and estimating the structural resilience of the bridge system to them. Finally, exposure levels and response to an event must be evaluated. So, the types and depth of bridge scour are an integral part of risk assessment for every bridge crossing a waterway [8].

\section{Scour along waterways}

Scour is the removal and transport of sediment from around hydraulic structures. As a natural process, sediments are constantly eroded, transported, and deposited along waterways. However, certain hydraulic conditions will erode large volumes of material from around bridge foundations that weaken their support capacity and compromise the safety of the superstructure.

Three primary terms are used to categorize scour, specifically general scour, contraction scours, and local scour. General scour includes the natural processes of aggradation and degradation of streambeds due to changing hydraulic parameters such as variations in flow discharge or sediment amount [9]. It drives the natural 
evolution of a waterway and results in the constant re-routing of the river channel when there are no natural or artificial obstacles [10].

Contraction scour occurs due to sudden channel geometry changes that constrict flow, causing an increase in water velocity. For example, bridge piers, shoreline facilities, hydraulic control structures, even ship traffic, can alter the channel crosssection and induce higher flow velocities. The increased speeds lead to higher sediment bed shear stresses, and if the stresses exceed the threshold level of the bed material, sediments mobilize and scour initiated [11].

The term "local scour" is given to describe erosion that occurs around hydraulic structures such as bridge piers and abutments (Fig. 1). An interacting set of unsteady flow features lifts and transports sediment from the pier foundation. They comprise flow impact with the pier face, creating a downward flow and an upward flow with a roller vortex; flow converging, constricting, then diverging; the creation, movement, and collapse of large scale turbulence in the foundation of the pier junction (horseshoe vortex, Fig. 1); a detaching shear layer where the pier crosssection curves back past its widest point; and, wake vortices generated through the pier's wake. The features evolve as scour develops. For example, when the water flow faces an obstruction such as a bridge pier, downward flow is convinced at the upstream end, causing localized corrosion around this construction [12]. The combined actions of the three forms of scour described may lead to significant losses in soil from around foundation elements.

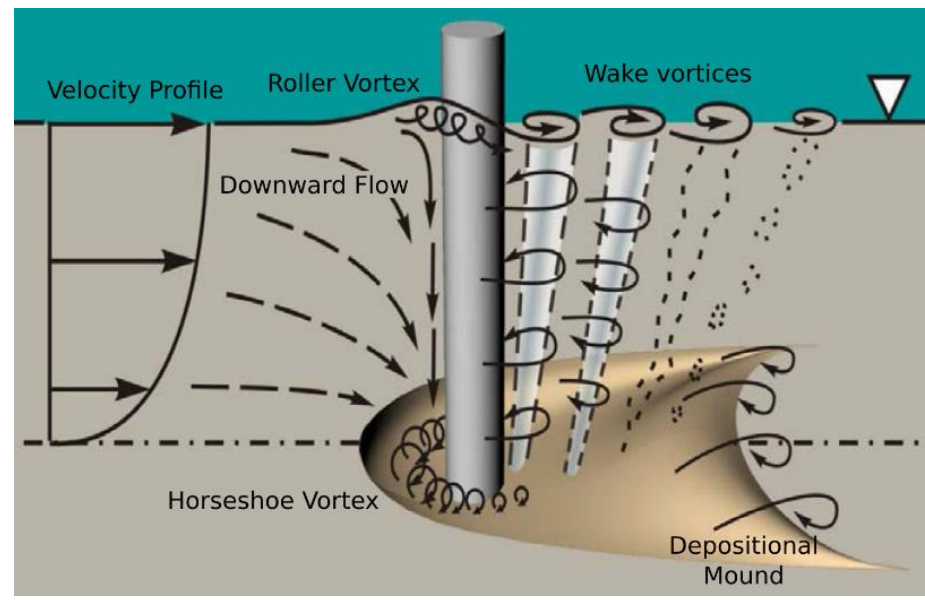

Figure 1. Local scour around the cylindrical pier in deep water, adapted from [13]. 


\section{Damage from scour}

Examples of scour causing serious bridge failures as the 1987 Schoharie Creek Bridge (Fig. 2a), part of Interstate-90 New York USA, where ten lives were lost. At the collapse, peak flow was $1,840 \mathrm{~m} 3 / \mathrm{s}$ with a $(70-100)$ year return period. The foundations of the four bridge piers were large spread footings $25 \mathrm{~m}$ long, $5.5 \mathrm{~m}$ wide, and $1.5 \mathrm{~m}$ deep without piles. The footings were set 1.5 meters into the streambed on highly dense ice contact layered glacial that the designers deemed nonerodible. Flume investigations of the stratified drift, on the other hand, revealed that some material would be eroded at $1.5 \mathrm{~m} / \mathrm{s}$, with substantial rates at $2.4 \mathrm{~m} / \mathrm{s}$. A $1: 50$ scale 3-D physical model study indicated a prototype flow velocity of $3.3 \mathrm{~m} / \mathrm{s}$ along the pier that failed. Additional modeling estimated $4.6 \mathrm{~m}$ of maximum scour depth. The prototype pier (pier 3) had a scour depth of 4.3 meters at the breakdown time. In 1995, the Arroyo Pasajero Bridge (Fig. 2b) on Interstate-5, California (USA), collapsed, killing seven people. The stream system is temporary (usually dry), with a sand bed having planar topography. While discharges were hard to quantify, the USGS using slope-area methods, determined that the 1995 discharge ranged 462$1,141 \mathrm{~m} 3 / \mathrm{s}$ with the best estimate of $773 \mathrm{~m}^{3} / \mathrm{s}$ and recurrence 75 years [14].

Factors contributing to the I-5 bridge failure were:

- Regional subsidence causing an increase in channel slope (higher velocities)

- The original design changed by placing a solid web wall between columns to repair damage from an earlier flood. The wall had an angle of attack from 15 to 26 degrees, blocking thru-flow and potentially increasing local pier scour depth by a factor of $3.6-4.4$

- There was a 33 percent increase in drainage area upstream from land-use change and a channel to link two streams.

- Long-term degradation of $3 \mathrm{~m}$ since the bridge was built

- Channel width reduction of 90 to $120 \mathrm{~m}$ to a bridge width of $37 \mathrm{~m}$. 


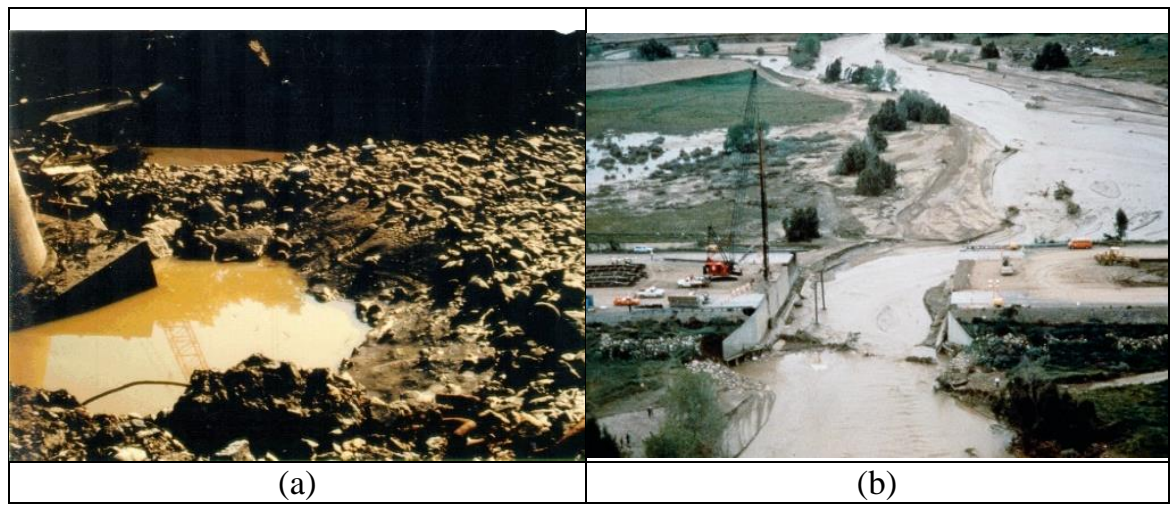

Figure 2. (a)Schoharie Creek Bridge [15] and (b) Arroyo Pasajero [14]

\section{Methods to monitor bridge scour}

Bridge designers can reduce scour through both hydraulic and structural countermeasures [15]. Hydraulic approaches may reduce abrupt flow expansion or contraction caused by poor streamlining, such as blunt pier faces. Such changes often lead to the generation of the vortices responsible for scour. Maintaining larger bridge openings at the design stage and streamlining pier geometries reduce vortex generation. Another critical factor is to keep openings clear by removing debris that often obstructs flow. However, deposits of the natural canal and upstream erosion may frequently modify the flow angle, and rationalized abutments pose similar difficulties. Structural features can be included during the design stage to locate spread footing below maximum scour depth and add rip-rap to the base of piers. This assumes the maximum depths are specific and hydraulic conditions will remain relatively constant over the bridge's lifetime. Another approach is based on the observational method where scour is monitored over time, and remediation works are implemented as needed [16]. When implemented correctly, this can be an efficient and economical method.

As part of a general bridge asset management scheme, visual inspection is the most common monitoring technique [17]. They often incorporate the employment of divers to check foundation elements and estimate their depth of scour by use of basic instruments with a structural examination [18]. Two important disadvantages of this method are that inspections during flooding are impossible, and scour holes tend to be filled in as floodwaters subside. Since scour holes may refill after flooding, misinterpretation of the inspection may hide the true extent of the scour problem.

Scour depth may be measured or monitored in a variety of ways. They include: 
- In-place devices that sense the presence (or absence) of soil. They may be penetration rods, floats with embedded switches, conductivity or dissolved oxygen sensors, or a variety of other approaches. They are often used when frequent or regular monitoring is required [15].

- Remote/portable sensors, which scan a greater area than sensors in (1) using sonar, geophysics, or similar concepts.

- Response analysis of the bridge, single pier, or abutment. Instead of measuring scour depth directly, they measure the effect of scour on the vibration response of the bridge or its components.

All the measuring and monitoring methods may be adopted into an overall program of operational health monitoring for the bridge. Each of these approaches has its advantages, and they are discussed further in the following sections

\subsection{Scour monitoring using in-place (fixed) instrumentation}

Most instrumentation fixed to the structure consists of sounding rods, driven rods with sensors, fathometers (sonar), buried transmitters, or tilt and vibration sensors. Table 1, presented at the end, lists a summary of all methods discussed here. Sonar devices can be mounted on the upstream face of the bridge pier and measure the distance to the stream bed. Measurements can be recorded continuously over any period to determine the depth of scour and refill during a high-flow event (Fig. 3a). Additional data logging and transmission equipment, as well as a solar panel or standard line power supply, would complete the package. Magnetic sliding collars (Fig. 3b) are rods attached to the face of a pier or abutment and driven into the streambed. A magnetic sensor collar is lowered to the streambed. If the streambed corrodes, the collar recession the rod into the scour hole, and the depth indicates the amount of scour. Magnets in the collar come into proximity with switches within the rod that close as the magnet slides into the scour hole. The data logger senses the switch condition and determines the level of the collar and scour activity. Magnetic sliding collars can only be used to monitor the maximum scour depth. Buried floatout devices can be active or inert buried sensors (Fig 3c) with a radio transmitter that may be active or awaiting activation. The signal, when engaged, is detected by a nearby receiver. The float-out is buried in a horizontal orientation and either transmits this state or does not transmit at all. When scour occurs to the depth of the device, it floats, changing its direction to vertical, and either activates (if previously dormant) or transmits a different signal. The receiver listens to the new signal and knows which device is sending it. Scour depth is based on the burial depth of the newly activated signal. The float-out sensor is easy to install in dry or nearly dry conditions, under armor stone and rip-rap, or at various pre-determined depths. Due 
to low power requirements, the float-out sensor can remain buried for many years and activate when released by scour activity [20].

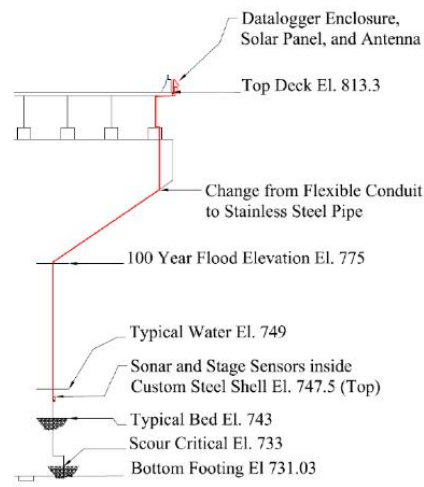

(a)

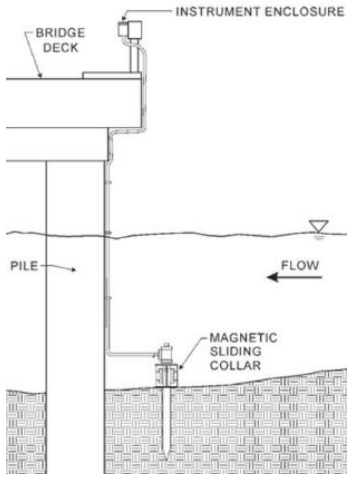

(b)

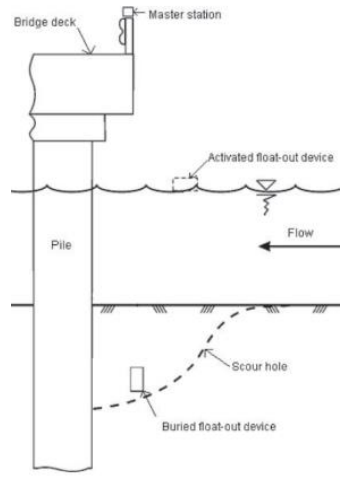

(c)

Figure 3. Fixed devices (a) sonar, (b) magnetic collars, (c) float-out device, modified from [21]

Other fixed systems may use sounding rods, time-domain reflectometry, or other sensors such as dissolved oxygen to report the scour depth. Sounding rods are placed on the surface of the river sediment (Fig. 4a). They have an enlarged base that will not penetrate the surface but move downward as the sediments erode beneath. An encoder box measures the downward movement and relays the information to the data collection/transmission system. Time-domain reflectometry (TDR, Fig. 4b) uses two wires to sense the dielectric environment outside the sensor. Sediments and water have different dielectrics, and the TDR device will detect the interface. Only the sensing length is used to measure depth. A tilt meter is sensitive enough to measure variations in abutment tilt (Fig. 4c) that may be a result of daily temperature changes, expected changes in water levels, or regular operations. Once those behaviours are catalogued, deviations from that behaviour would trigger an alarm that warns engineers to check the bridge for dangerous conditions. With some further calibration and analysis, the cause of the unusual behaviour may be determined. Vibration monitors are worked similarly; however, this approach uses the principle of calculating the critical occurrence of the rod fixed in the streambed. The opposite relationship between fundamental frequency and the sensor of the rod length is applied to monitor scour depth. It uses structural vibration sensors, such as accelerometers or fiber-optic (FBG) devices, to be used as the scour sensor's dynamic sensing feature. However, this approach is yet to be thoroughly tested. It is continuing research, and studies are being carried out on it [22]. 
All of the in-place instruments are limited to a small area of interest immediately surrounding the probe. They give little information about the areal extent of scour or specific hydraulic conditions (aside from depth of scour).

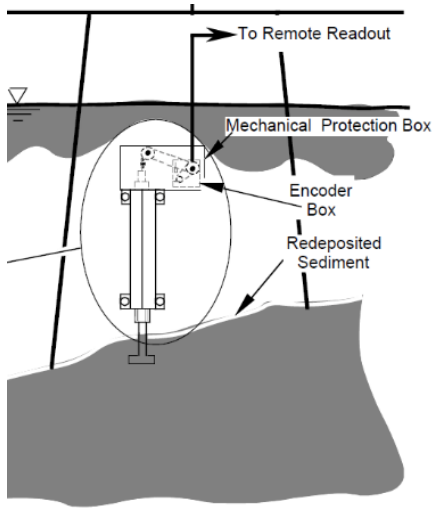

(a)

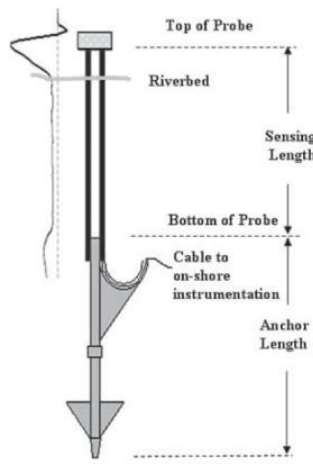

(b)

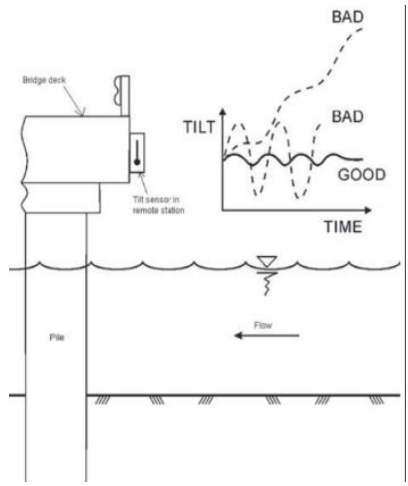

(c)

Figure 4. In-place measurements (a) recording sounding rod, (b) TDR probe, (c) tilt meter [9, 21]

\subsection{Scour monitoring using portable instrumentation}

Schall and Price [23] presented an extensive discussion on the theory and practice of using portable monitoring equipment. Being written in 2004, much of the technology is less expensive, but many of the concepts, design processes, and practical problems with deployment and handling are still the same. Portable instruments include four components:

- The measuring instrument (sonar, geophysical, etc.)

- The system to deploy the instrument (crane, paddleboard, remotecontrolled boat, drone).

- Method to record horizontal (x, y) position of the instrument. It may also include some vertical $(\mathrm{z})$ references as well.

- Data storage and transmission.

With newer technologies, components 3 and 4 have become much more economical and efficient. RTK GNSS modules, weighing $35 \mathrm{gm}$, can record location information with centimetre accuracy for less than 500 euro [21]. Data storage options can be on-device with SD cards holding 128GB+ of data or transmitted to a receiver station or smartphone. With higher accuracy come different challenges: one must know the 
various locations of the RTK module and the sensor. If the sensor is moving, then any time lag between sensor trigger and position report will impact the sensor's reported vs. actual location.

Sonar systems use a variety of transponders and methods. Generally, the signal is a narrow beam to reduce the possibility of signal averaging over a wider area. Monitoring concepts for structural structures have been through a steady growth phase over the last decade. As a result, they play a role in the design of new and emerging architectures. This chapter briefly reviews a selection of the more often used scour detection and measuring techniques. In terms of the instruments used, they are divided into portable instrumentation methods and integrated instrumentation methods. Mobile instrumentation methods include Physical probing, fathometers (Sonar), and Geophysical information, while fixed or integrated instrumentation methods include buried RF sensors, sonar, and other similar devices [24] as shown in Fig. 5.
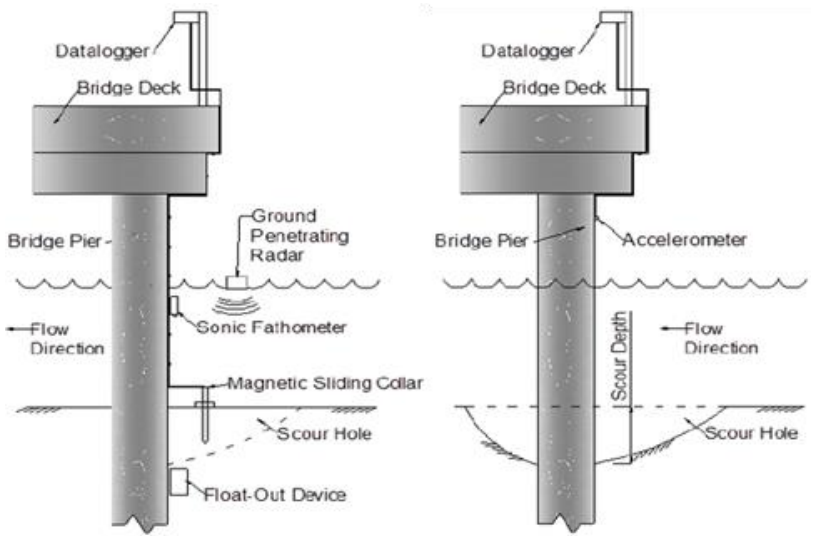

Figure 5. Portable (mobile) system measurement [26].

\subsubsection{Fathometers and Manned ships}

Fathometers or acoustic depth sounders are commonly used for portable scour measurements. In addition, precision survey-grade hydrographical survey fathometers and fish finders are used. Transducers are fixed to a pole, hand-line, tethered buoy, or boom while measurements are taken from the bridge. Kneeboards and pontoon-style floats are examples of tethered float platforms. In fast-moving, swirling water, the size of the float is critical for stabilization. In addition, a bridge inspection truck can deploy floating or non-floating structures. When the bridge is well over the river, this is especially helpful. For instance, bridges more than 15 
meters above the sea are usually inaccessible from the bridge surface unless this method is used.

[25] Created an articulated arm to position a sonar transducer. The machine was trailer-mounted and could be used on bridge decks ranging from 5 to 15 meters above the water's level. An onboard computer measured the transducer's orientation about a known location on the bridge deck based on the boom's angle and the space between the boom pivot and the transducer.

Manned ships are used as a scour measurement platform. They usually need enough distance below the bridge and near the launch facilities. During floods, it may be a challenge as the river level can exceed or submerge the bridge's low chord, and boat ramps may be submerged. A fathometer is typically used for depth measurements, and GPS devices are usually used for location. The construction of an unscrewed prototype boat was prompted by concerns about safety, launching, and approval. A compact flat-bottomed jon yacht, an 8-hp outboard engine, a fathometer, and GPS with remote controls are applied. It was put to the test through six floods with great results [25].

The benefit of GPS over conventional land-based intrusion detection eliminates the need for line-of-sight between control points. GPS can be used at night and in inclement weather, particularly useful for scour tracking during floods. The downside of GPS is that it cannot be used in parts where the overhead obstructions, such as tree canopy or bridge decks. Though, GPS measurements up to the bridge face have been accurate without going under the bridge.

\subsubsection{Sonar and Geophysical Techniques}

The interfaces between different resources with different physical characteristics are determined by geophysical instruments based on wave spread and reproduction measurements. Sonar and geophysical techniques vary in that geophysical approaches have sub-bottom detail, while sonar can only detect the water-soil interface and not reach the sediment layer. The key differences between various geophysical techniques are the kinds of signals emitted and the physical property modifications that produce reflections. Like sonar, a seismic instrument uses acoustic waves but at a lower range $(2-16 \mathrm{kHz})$. Seismic sounds, like sonar, are susceptible to being dispersed by air bubbles and high sediment concentrations [27]. The best use of geophysical technology is to assess scour depth in infilling areas during a flood under lower flow conditions. The equipment's expense and complexity and the data's interpretation restrict widespread usage and use as a portable scour monitoring system. More developed, minor price GPR devices with electronic data dispensation capability have been recognized, these issues have 
lessened. However, expense and difficulty and the need for borehole details and reliable bridge plan details to calibrate and interpret the results can also restrict GPR.

\subsubsection{Diving Probing and sound rods}

Diving is a basic scour screening system in which a trained bridge inspector conducts a manual inspection of the bridge underwater. This system will capture scour data from various sites, and the water clarity does not affect the data collection process. However, the downside of this approach is that it can be costly, making it more ideal for worst-case cases. It also has a strong potential for risk. Furthermore, owing to the subjectivity of the regulators, the data produced from such visual inspections may have a high degree of uncertainty [28]. A sound rod is used for the bridge inspector to manually test a bridge by placing a rod or weight on the streambed to determine the sediment depth. The bottom of the rod must be wide to keep the rod from entering the streambed due to the rod's weight and friction induced by running water. When the riverbed is sand, sounding rods appear to go into the streambed, affecting their accuracy. Diving probing has many advantages, including the fact that it is not compromised by air entrainment or heavy sediment levels, and it can be used in fast, shallow water. The critical problem with this approach is the inaccuracy of the data samples gathered and the possible risks inherent with this method. Besides, this approach can be costly and does not have the capability of automatic warnings.

\subsection{Applying other new methods for scour detection}

The soil-structure interface mechanism is complicated during scour. However, the material displacement under (or around) the base during scour induces increased tension and decreased residual soil stiffness. Although the vibration of the structure depends on the device's rigidity, the observation of variations in vibration rates is a possible tool for detecting damage and monitoring health. The framework's average frequency related to the bridge piers could be found by applying spectral analysis approaches, for example, the FFTs accelerometers equestrian and frequency domain fragmentation on the bridges. The underwater instruments have often been used to calculate the progression of the scour depths over time. However, few investigations have been accompanied to understand the impact of the scour on the bridge system's reaction. Some of the instruments designed to test the bridge structure's reaction to the scour including tilt-meters which measure the comparative variation of the structural feature and, as such, also for distinguishing differential settlements that may happen as a consequence of the scour process. The only significant drawback of the system is that it does not straight designate the scour's extent. Devices capable of specifically assessing structural distress are expected to help engineers undertake the necessary repair arrangements for critical structures before the collapse. 
Furthermore, Accelerometers are used to compute the structural reaction, especially in a change in boundary conditions [19].

There has been a spectral analysis reaction, and an elastic reaction spectrum of the seismic guidelines was created for this method of analysis that characterizes the activities of the earthquake [29]. In addition, a nonlinear study of the complex past of time was conducted to detect the potential behind non-elastic conditions. The principal findings are that the continuum analysis of reactions is an estimated method for assessing the optimum importance of inner forces and the nonlinearity of the pier segment reduces the inner forces and movement compared to linear analysis. This method could be considered a possible tool for detecting bridge damage and monitoring health, and distinguishing differential settlements that may happen due to the scouring process.

An Internet of Things (IoT) and Artificial Intelligence (AI) combination scoring system is created and deployed to get real-time measurements in scour depth. These vibration-based MEMS devices are packaged in a water-resistant steel ball in a barrel cage to survive extreme flooding. First, the fluvial water-level fluctuations surrounding the jetty are made using the Mask R-CNN profound learning model with real-time CCTV pictures (Fig. 6). Then, the scour-depth development is simulated with the hydrodynamic model and the sediment transport formula using the specified local scour formulas [30]. The overall performance of the hydrodynamic modelling is reasonable, based on the technique stated above, for whole scour-depth development. Moreover, it can anticipate scour-depth changes in bridge failure for early warning.

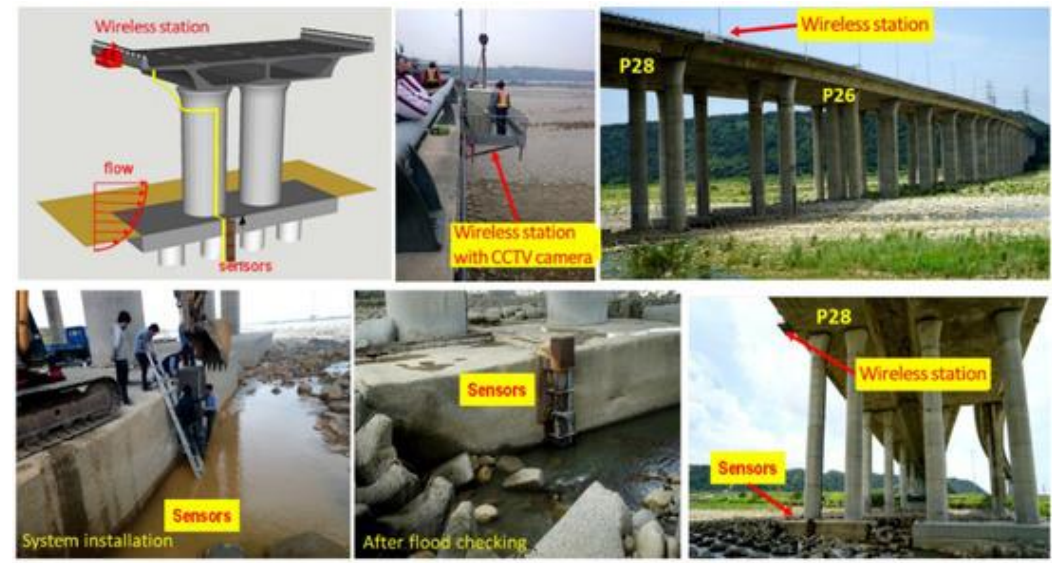

Figure 6. Fixing of the scour observing scheme, sensors, and the wireless station [30]. 


\section{Summary}

The author summarises the main results in Table 1 and Table 2 that contain the relevant methods, their tools, and experiments, as well as the properties of the methods based on international literature.

\section{Conclusion}

All methods presented in scour detection are costly in monetary costs, and more human resources are required. Therefore, instead of investing so much money on new gadgets, sensors can be used that are already integrated into our smartphones. A primary mobile phone, which anybody can use, can identify scour beneath bridges foundation (piers and abutments). The key aim is to minimize human effort in identifying scour by using a quick, easy-to-use, cost-effective process, resulting in minor injury due to bridge collapse.

Conversely, traditional procedures mostly use underwater tools to detect bridge scour depths and shape, which are also difficult to distinguish in instrument deployments and facilities. Recently, the method of Vibration-based destruction monitoring has been discovered to overcome specific difficulties by investigating the natural frequency range of a bridge or bridge part. Additionally, the advancement of these fixed and portable scour measurement devices, along with GPS, remotely operated ships, instrumented vehicles, and knowledge of the need to calculate and monitor bridge spacing, have greatly enhanced the scour database, methods for forecasting spacing depths, bridge scour and bridge protection. 


\section{Table 1. The portable bridge scour instrumentation detection methods}

\begin{tabular}{|c|c|c|}
\hline & Tools and experiments & Properties \\
\hline 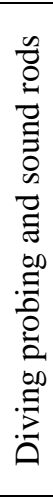 & $\begin{array}{l}\text { - A basic scour screening system in } \\
\text { which a trained bridge inspector } \\
\text { conducts a manual inspection of the } \\
\text { bridge underwater. } \\
\text { - A sound rod is used for the bridge } \\
\text { inspector to manually test a bridge } \\
\text { by placing a rod or weight on the } \\
\text { streambed to determine the sediment } \\
\text { depth. }\end{array}$ & $\begin{array}{l}\text { - Capture scour data from a variety of sites, and } \\
\text { the water clarity does not affect the data } \\
\text { collection process. } \\
\text { - It can be costly, making it more ideal for worst- } \\
\text { case cases. } \\
\text { - It is a strong potential for risk. } \\
\text { - Owing to the subjectivity of the regulators, the } \\
\text { data produced from such visual inspections may } \\
\text { have a high degree of uncertainty. } \\
\text { - It is not compromised by air entrainment or } \\
\text { heavy sediment levels, and it can be used in fast, } \\
\text { shallow water. } \\
\text { - The critical problem with this approach is the } \\
\text { inaccuracy of the data samples gathered and the } \\
\text { possible risks inherent with this method. }\end{array}$ \\
\hline 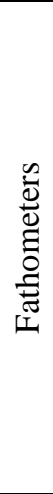 & $\begin{array}{l}\text { - Acoustic depth sounders are } \\
\text { commonly used for portable scour } \\
\text { measurements. } \\
\text { - Precision survey-grade } \\
\text { hydrographical survey fathometers } \\
\text { and fish finders are used. } \\
\text { - Transducers are fixed to a pole, } \\
\text { hand-line, tethered buoy, or boom. } \\
\text { - Kneeboards and pontoon-style floats } \\
\text { are examples of tethered float } \\
\text { platforms } \\
\text { - Articulated arm to position a sonar } \\
\text { transducer.. } \\
\text { - Manned ships are also used as a } \\
\text { scour measurement platform. }\end{array}$ & $\begin{array}{l}\text { - A bridge inspection truck can deploy floating or } \\
\text { non-floating structures. } \\
\text { - The advantage of GPS over traditional land- } \\
\text { based vulnerability scanning is that it reduces } \\
\text { the need for line-of-sight among control points. } \\
\text { - The GPS may be used at night and in inclement } \\
\text { weather, which can be especially useful for } \\
\text { flood monitoring. } \\
\text { - The downside of GPS is that it cannot be used } \\
\text { in parts where overhead obstructions, such as } \\
\text { tree canopy or bridge decks. } \\
\text { - GPS measurements up to the bridge face have } \\
\text { been accurate without going under the bridge. }\end{array}$ \\
\hline 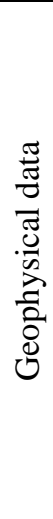 & $\begin{array}{l}\text { - The interfaces between different } \\
\text { resources with different physical } \\
\text { characteristics are determined by } \\
\text { geophysical instruments based on } \\
\text { wave spread and reproduction } \\
\text { measurements. } \\
\text { - Sonar and geophysical techniques } \\
\text { vary in that geophysical approaches } \\
\text { have sub-bottom detail, while sonar } \\
\text { can only detect the water-soil } \\
\text { interface and not reach the sediment } \\
\text { layer } \\
\text { - More developed, minor price GPR } \\
\text { devices with electronic data } \\
\text { dispensation capability have been } \\
\text { renowned. }\end{array}$ & $\begin{array}{l}\text { - Differences between various geophysical } \\
\text { techniques. Like sonar, a seismic instrument } \\
\text { uses acoustic waves at a lower range (2-16 } \\
\text { kHz). } \\
\text { - The best use of geophysical technology is to } \\
\text { assess scour depth in infilling areas during a } \\
\text { flood under lower flow conditions } \\
\text { - The equipment's expense and complexity and } \\
\text { the data's interpretation restrict widespread } \\
\text { usage and use as a portable scour monitoring } \\
\text { system. } \\
\text { - Expense, difficulty, and the need for borehole } \\
\text { details and reliable bridge plan details to } \\
\text { calibrate and interpret the results can also } \\
\text { restrict GPR. }\end{array}$ \\
\hline
\end{tabular}




\section{Table 2. The fixed bridge scour instrumentation detection methods}

\begin{tabular}{|c|c|c|}
\hline Methods & Tools and experiments & Properties \\
\hline 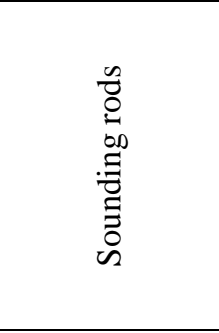 & $\begin{array}{l}\text { The binding of the rod in its } \\
\text { supporting enclosure (pipe), } \\
\text { The producer (Cayuga } \\
\text { Industries) and the USGS on } \\
\text { coarse-bed streams } \\
\text { - long probes installed in the } \\
\text { stream bed at the point of } \\
\text { interest. }\end{array}$ & $\begin{array}{l}\text { - A substantial depth of scouring, in sand-bed } \\
\text { streams, sand deposited between the rod and } \\
\text { its supporting section would also tie it up } \\
\text { - In sand-based non-cohesive bed materials, } \\
\text { the rod would penetrate a considerable and } \\
\text { indeterminate volume into the bed } \\
\text { - It could be costly and timewasting. } \\
\text { - The precision of the measurement is affected } \\
\text { by varying temperatures in the channel, with } \\
\text { relative errors of 5\% reported in some studies }\end{array}$ \\
\hline 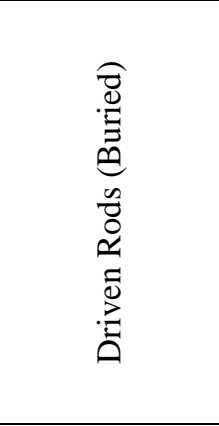 & $\begin{array}{l}\text { Both sensors and instruments } \\
\text { supported by a vertical support } \\
\text { member such as a shaft, rail, or } \\
\text { column mounted vertically in } \\
\text { the bed } \\
\text { - The gravity sensor is placed in } \\
\text { the stream bed near the guided } \\
\text { rod scheme. } \\
\text { - A remote sensing component is } \\
\text { typically used to detect } \\
\text { changes in the depth of the } \\
\text { gravity sensor. }\end{array}$ & $\begin{array}{l}\text { - This system offers a reasonably easy method } \\
\text { for tracking the scour depth's advancement. } \\
\text { - There is a range of drawbacks as Scour } \\
\text { depths may only be noticed in the } \\
\text { instrument's immediate vicinity, meaning } \\
\text { that several devices could be needed to catch } \\
\text { the scour's actual (global) effect. } \\
\text { - The element uses a gravity device that } \\
\text { remains at the deepest depth of the scour } \\
\text { throughout each flood incidence. This means } \\
\text { that it will have to be reset, which could be } \\
\text { costly and timewasting, and would not } \\
\text { include details on the scour hole's refilling }\end{array}$ \\
\hline 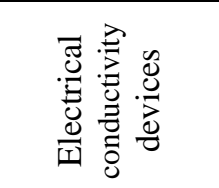 & $\begin{array}{l}\text { Use the variations in the } \\
\text { different media's electrical } \\
\text { conductivity to determine the } \\
\text { water-sediment interface's } \\
\text { direction using two probes }\end{array}$ & $\begin{array}{l}\text { - As the material between the probes varies, the } \\
\text { capacity to draw a current would also change. } \\
\text { - This phenomenon can be used to show the } \\
\text { presence and extent of the scour. }\end{array}$ \\
\hline 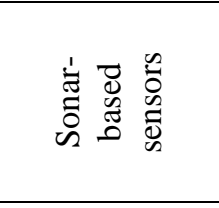 & $\begin{array}{l}\text { permanent devices that are } \\
\text { typically mounted on the pier } \\
\text { and abutment. } \\
\text { - Sonar emits pulse waves and } \\
\text { processes the trip portable time } \\
\text { of a pulse from the riverbed. }\end{array}$ & $\begin{array}{l}\text { - Both scour, and accumulation of sediments } \\
\text { can be measured using sonar sensors } \\
\text { - The measurements are influenced by heavy } \\
\text { sediment and turbulent flow in the sea. } \\
\text { - High-end sonars with a large depth capacity } \\
\text { and high resolution can be costly }\end{array}$ \\
\hline 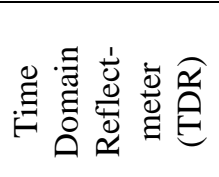 & $\begin{array}{l}\text { Time Domain Reflect-meter } \\
\text { (TDR) based approaches use a } \\
\text { similar sonar approach to } \\
\text { measure scour. }\end{array}$ & $\begin{array}{l}\text { - Determining the portion of the conduits } \\
\text { submerged in the stream bed. } \\
\text { - TDRs are capable of repeatable } \\
\text { measurements and are very durable. } \\
\text { - involve much fuel, making them costly. }\end{array}$ \\
\hline 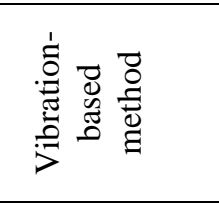 & $\begin{array}{l}\text { Calculating by the essential } \\
\text { occurrence of the rod fixed in } \\
\text { the streambed. } \\
\text { - It uses structural vibration } \\
\text { sensors, such as accelerometers } \\
\text { or fiber-optic (FBG) devices. }\end{array}$ & $\begin{array}{l}\text { To monitor scour depth, the opposite } \\
\text { relationship between essential frequency and } \\
\text { the sensor of the rod length is applied. } \\
\text { - This approach is yet to be thoroughly tested. } \\
\text { and studies are being carried out on it. }\end{array}$ \\
\hline
\end{tabular}




\section{Acknowledgment}

Professor Csaba Koren helped and supported the publishing of this paper in Széchenyi István University as part of the New solutions in the design of road and railway infrastructure course submission.

\section{References}

[1] K. Faulkner, J. Brownjohn, Y. Wang et al., Tracking bridge tilt behaviour using sensor fusion techniques, Journal of Civil Structural Health Monitoring 10 (4) (2020) pp. 543-555.

doi: https://doi.org/10.1007/s13349-020-00400-9

[2] L. J. Prendergast, K. Gavin, A review of bridge scour monitoring techniques, Journal of Rock Mechanics and Geotechnical Engineering 6 (2) (2014) pp. 138-149.

doi: https://doi.org/10.1016/j.jrmge.2014.01.007

[3] Z. Van Leeuwen, R. Lamb, Flood and scour related failure incidents at railway assets between 1846 and 2013, Railway Safety and Standards Board, 2014 [cited 2021-06-29].

URL https://www. jbatrust.org/how-we-help/publicationsresources/risk-analysis/flood-and-scour-related-failureincidents-at-railway-assets/

[4] C. Montalvo, W. Cook, T. Keeney, Retrospective analysis of hydraulic bridge collapse, Journal of Performance of Constructed Facilities 34 (1) (2020): 04019111.

doi: https://doi.org/10.1061/(ASCE) CF.1943-5509.0001378

[5] R. J. Dawson, D. Thompson et al., A systems framework for national assessment of climate risks to infrastructure, Philosophical Transactions of the Royal Society A: Mathematical, Physical and Engineering Sciences (2018): 20170298.

doi: https://doi.org/10.1098/rsta.2017.0298

[6] F. Nemry, H. Demirel, Impacts of Climate Change on Transport: A focus on road and rail transport infrastructures, European Commission, Joint Research Centre (JRC), Institute for Prospective Technological Studies (IPTS), 2012. 
[7] E. B. Williamson, G. David, Risk management and design of critical bridges for terrorist attacks, Journal of Bridge Engineering 10(1) (2005) pp. 96-106. doi: https://doi.org/10.1061/(ASCE) 1084-0702 (2005) 10:1 (96)

[8] J. L. Briaud, P. Gardoni, C. Yao, Statistical, risk, and reliability analyses of bridge scour, Journal of Geotechnical and Geoenvironmental Engineering 140 (2) (2014) . doi: https://doi.org/10.1061/(ASCE) GT.1943-5606.0000989

[9] M.C. Forde, D. M. McCann et al., Radar measurement of bridge scour, Independent Non-destructive Testing and Evaluation International 32 (8) (1999) pp. 481-492.

doi: https://doi.org/10.1016/S0963-8695(99)00026-2

[10] F. Federico, G. Silvagni, F. Volpi, Scour vulnerability of river bridge piers, Journal of Geotechnical and Geoenvironmental Engineering 129 (10) (2003) pp. 890-899.

doi: https://doi.org/10.1061/(ASCE) 10900241 (2003) 129:10(890)

[11] J. L. Briaud, F. C. Ting et al., SRICOS: Prediction of scour rate in cohesive soils at bridge piers, Journal of Geotechnical and Geoenvironmental Engineering 125(4) (1999) pp. 237-246.

doi: https://doi.org/10.1061/(ASCE) 10900241 (1999) 125:4(237)

[12] D. Ryan, G. A. Hamill et al., The hydraulics and resulting bed scour within the vicinity of Submerged Single Span Arch Bridges, In Civil Engineering Research in Ireland, 2014 [cited 2021-06-19].

URL

https://pureadmin.qub.ac.uk/ws/portalfiles/portal/1353868

2/The_hydraulics_and_resulting_bed_scour_within_the_vicin ity_of_Submerged_Single_Span_Arch_Bridges.pdf

[13] R. Ettema, B.W. Melville, G. Constantinescu, Evaluation of bridge scour research: Pier scour processes and predictions, National Cooperative Highway Research Program Transportation Research Board of the National Academies, Washington, DC, USA, 2011. 
[14] E.V. Richardson, Photo collection, Library Archive, Colorado State University (1995) [cited 2021-05-11].

URL https://mountainscholar.org/handle/10217/170449

[15] P. F. Lagasse, L. W. Zevenbergen et al., Bridge scour and stream instability countermeasures: experience, selection, and design guidance: Volume 2. No. FHWA-NHI-09-112, National Highway Institute, USA, 2009.

[16] J. L. Briaud, S. Hurlebaus et al., Realtime monitoring of bridge scour using remote monitoring technology, No. Report 0-6060-1. Texas Transportation Institute, USA, 2011.

[17] L. J. Prendergast, K.Gavin, A review of bridge scour monitoring techniques, Journal of Rock Mechanics and Geotechnical Engineering 6(2) (2014) pp. 138-149.

doi: https://doi.org/10.1016/j.jrmge.2014.01.007

[18] R. R. Avent, M. Alawady, Bridge scour and substructure deterioration: Case study, Journal of Bridge Engineering 10(3) (2005) pp. 247-254.

doi: https://doi.org/10.1061/(ASCE) 1084-0702 (2005) 10:3 (247)

[19] S. Foti, D. Sabia, Influence of foundation scour on the dynamic response of an existing bridge, Journal of bridge engineering 16(2) (2011) pp. 295-304. doi: https://doi.org/10.1061/(ASCE) BE.1943-5592.0000146

[20] B. E. Hunt, Monitoring scour critical bridges: a synthesis of highway practice, The National Cooperative Highway Research Program Synthesis Report, 2009.

[21] L. J. Zabilansky, Ice force and scour instrumentation for the White River, Vermont, Cold Regions Research and Engineering Lab Hanover N, US Army Corps of Engineers, USA, 1996.

[22] A. Zarafshan, A. Iranmanesh, F. Ansari, Vibration-based method and sensor for monitoring of bridge scour, Journal of bridge engineering 17(6) (2012) pp. 829-838.

doi: https://doi.org/10.1061/(ASCE) BE.1943-5592.0000362 
[23] J. D. Schall, G. R. Price, Portable scour monitoring equipment (Vol. 515), Transportation Research Board, 2004.

URL http://www.trb.org/Publications/Blurbs/154328.aspx

[24] N. Anderson, A. Ismael, T. Thitimakorn, Ground-penetrating radar: a tool for monitoring bridge scour, Environmental \& Engineering Geoscience 13(1) (2007) pp. 1-10.

doi: https://doi.org/10.2113/gseegeosci.13.1.1

[25] D. S. Mueller, M. N. Landers, Portable instrumentation for real-time measurement of scour at bridges (No. FHWA-RD-99-085), Federal Highway Administration, United States, 2000.

[26] L.J. Prendergast, K. Gavin, Monitoring of scour critical bridges using changes in the natural frequency of vibration of foundation piles-A field investigation, In Transport Research Arena, Paris, France, 2014.

[27] N. E. Yankielun, L. Zabilansky, Laboratory investigation of time-domain reflectometry system for monitoring bridge scour, Journal of Hydraulic engineering 125(12) (1999) pp. 1279-1284.

doi: https://doi.org/10.1061/(ASCE) 07339429(1999) 125:12(1279)

[28] W. Zheng, Instrumentation and computational modeling for evaluation of bridges substructures across waterways (No. FHWA/MS-DOT-RD-13-229). Department of Transportation, Mississippi, USA, 2013.

[29] M. Brinissat, R. Kuti, Z. Louhibi, Dynamic seismic analysis of bridge using response spectrum and time history methods, Acta Technica Jaurinensis (2021) pp. 171-185.

doi: https://doi.org/10.14513/actatechjaur.00595

[30] Y. B. Lin, F. Z. Lee et al., The artificial intelligence of things sensing system of real-time bridge scour monitoring for early warning during floods, Sensors 21(14) (2021) pp. 1-18.

doi: https://doi.org/10.3390/s21144942 